Yasko Yulia, $\mathrm{PhD}$ in Economics, Kyiv National University of Trade and Economics, Kyiv, Ukraine

ORCID: 0000-0002-8756-4612

ResearcherID: B-9894-2019

\title{
FORMING A FAVORABLE BUSINESS ENVIRONMENT IN THE GLOBALIZATION CONDITIONS
}

Investigated the basic tendencies and problems of forming of business environment in Ukraine. Substantiated the impact of globalization on the activities of domestic entities. Analyzed the indicators of favorable business conditions in the World Bank's Doing Business rating. Determined priority vectors and features of formation of favorable business environment in economy.

Keywords: business environment, competition, competitiveness, globalization.

Ясько Юлія. Формування сприятливого бізнес-середовища в умовах глобалізації.

Досліджено основні тендениї та проблеми формування бізнес-середовища в Украӥні. Обтрунтовано вплив глобалізачії на діяльність вітчизняних суб'єктів господарювання. Проаналізовано показники сприятливості умов ведення бізнесу в рейтингу Світового банку Doing Business. Визначено пріоритетні вектори та особливості формування сприятливого середовища для ведення бізнесу в економіці.

Ключові слова: бізнес-середовище, конкуренція, конкурентоспроможність, глобалізаиія.

Relevance of research topic. The current stage of development of the world economic system is characterized by the increasing interdependence of the economies of different countries, the intensification of integration processes and the rapid transition of developed countries to an innovative type of economy, which requires timely adaptation to the influence of external factors in the formation of a competitive national economy.

Creating a favorable business environment is a source of sustainable socioeconomic development that directly influences the improvement of the standard and quality of populations life. Sustainable economic growth in the country is impossible without successful business development, which requires the development and 
implementation of an effective mechanism to stimulate it. It requires constant adaptation of the conditions of functioning of national economic entities to the tendencies of the global business environment and the corresponding reaction from the state.

Formulation of the problem. The problem of forming a favorable business environment as an important component of market systems cannot be diminished, given its potential impact on the economic development of society.

The state of development of the business environment forms a significant factor influencing the processes that occur in the national economy as a whole. This determines the relevance of research into problematic issues related to the creation of a favorable environment for the activities of economic entities, ensuring a level playing field, as well as the formation of effective market structures and institutions that will enhance the competitiveness of both individual and national entities. economy as a whole.

Analysis of recent research and publications. Researches of certain aspects of the formation of the business environment can be found in the works of domestic and foreign scientists: R. Coase [2], A. Galchinsky [4], V. Heits [5], S. Khalatur [6], V. Lipov [7], A. Mazaraki [8], M. Porter [10], J. Schumpeter [12], Y. Zhalilo [13] and others. However, despite the existence of some scientific achievements, the important scientific and practical problem of creating a favorable business environment in Ukraine remains unresolved.

Presenting main material. In the economic literature, the business environment is seen as a complex and multidimensional system. The business environment is understood to mean the totality of all external and internal factors of the enterprise, which greatly affect its functioning [1, p. 26].

According to the definition of the World Bank, the business environment consists of a set of institutional, legislative and regulatory conditions under which the business operates [3].

We think that the business environment is the set of individual economic entities and their interconnections, and also the factors of internal and external environment that create the conditions for their functioning. Such major factors include consumers of products, suppliers, competitors, government regulation, as well as economic, social, political, technological, legal and environmental conditions.

At different stages of historical development, different forms of relations of state power with economic entities prevailed, which led to the formation of quite different types of relations between them, and therefore - different economic and political models of state policy, centered around two classical models - the conductor and liberal.

In the context of intense globalization transformations, the orientation towards liberalization of the economy becomes especially relevant through the creation of a favorable institutional environment in order to stimulate entrepreneurial activity and 
stimulate economic growth in the country. In a liberal business environment model, private business itself looks for growth points, financial and investment support for innovative projects.

However, as noted by Y. Zhalilo, «one of the main paradoxes of globalization is the combination of the trends of economic integration on a global scale with the trends of economic disintegration at the levels of national economies. By separating one of the leading «contours» of the economic system - capital flow and income on them economic globalization directly interferes with the key regulator of competition in the national market - intra-industry and inter-industry flow of capital, modifying the content of competition. Therefore, globalization requires a parallel strengthening of the internal integration of the national economy through a powerful national market. Preserving national economic integrity is only possible through the participation of national governments in a kind of «competition» for the better business environment» [13].

Scientific discussions of representatives of different economic policy areas did not lead to one of the approaches. Today, the economic policies of most developed countries combine several approaches. Therefore, a mixed model of business environment is a symbiosis of market and state influence on the formation of favorable business conditions, the availability of equal organizational capabilities of all subjects of economic relations. An example of the successful implementation of such a model is the Japanese economy, which has developed a strategy based on taking into account the economic interests of all actors, thus expanding the economy as a whole. The state and business entities pursued a common policy of foreign economic expansion in the international market in the direction of improving the functional and territorial organization of the economy, improving the standard and quality of life of the population of the country.

The involvement of our country in the integration processes requires a search for effective and dynamic models of macroeconomic equilibrium, application of effective methods of regulating the economy, the rationale for the extent of intervention in economic processes and state policies on the principles of preservation and protection of the economic interests of the country and its economic actors. The priority directions of the state economic policy should be the creation of balanced proportions and development of reproduction processes in the economy. It is important that government economic policies were developed not from a position of restriction of competition, but from the standpoint of saving in the domestic market of Ukraine, its integrity, on the basis of realization of competitive advantages of Ukraine.

The key to Ukraine's high competitiveness at the international level is to increase the efficiency and productivity of a diversified national economy, which should be based on a powerful technological, scientific and investment base [6, p. 22].

The intensification of competition in the domestic and foreign markets, the emergence of new forms and methods, significant differentiation of consumer demand require the search for priority areas for obtaining competitive advantages by domestic 
enterprises in the context of intensification of globalization-integration processes and modern crisis transformations in the national crisis [9, p. 110].

In today's world, competition from microeconomic entities is turning into an instrument of global competition from states in the form of economic models, modes of support for national producers in foreign markets, which can ultimately ensure the quality of citizens life. The result is fixed by the country's place in the global economy. Its entry into the core, proto-periphery or periphery of the world-system is confirmation of the level of development, criterion of success of international integration, indicator of interest of partners in interaction with it, rating in the global system of redistribution of value [7, p. 22].

In order to identify problems and identify priority vectors for the development of a favorable business environment in Ukraine, an analysis of the ease of doing business in Ukraine was conducted based on Doing Business World Bank ranking data. This research will help to determine the prospects of Ukraine's participation in the global innovation process.

So, let's look at the main indicators of business environment development in Ukraine. In 2019, Ukraine ranked 71st among 190 countries in the Doing Business World Bank's annual ranking, which is 5 positions higher than in the previous year (Table 1). Experts of the World Bank note that advancement in the rating allowed Ukraine to improve in terms of protection of minority shareholders (from 81 to 72 positions), simplification in terms of obtaining building permits (increase from 35 to 30 places). In addition, improvements in international trade were noted - trade across borders was simplified, eliminating the inspection of auto parts requirements by the State Export Control Service (promotion from 119 to 78 places) (Table 2).

Table 1

Rating of ease of doing business (individual countries) in 2018-2019*

\begin{tabular}{|c|c|c|c|}
\hline Country & Rank 2019 & Country & Rank 2018 \\
\hline New Zealand & 1 & New Zealand & 1 \\
\hline Singapore & 2 & Singapore & 2 \\
\hline Denmark & 3 & Denmark & 3 \\
\hline Hong Kong & 4 & South Korea & 4 \\
\hline South Korea & 5 & Hong Kong & 5 \\
\hline Georgia & 6 & USA & 6 \\
\hline Norway & 7 & United Kingdom & 7 \\
\hline USA & 8 & Norway & 8 \\
\hline United Kingdom & 9 & Georgia & 9 \\
\hline Northern Macedonia & 10 & Sweden & 10 \\
\hline Lithuania & 14 & Lithuania & 16 \\
\hline Poland & 33 & Poland & 27 \\
\hline Czech Republic & 35 & Czech Republic & 30 \\
\hline
\end{tabular}




\begin{tabular}{|c|c|c|c|}
\hline Country & Rank 2019 & Country & Rank 2018 \\
\hline Belarus & 37 & Belarus & 38 \\
\hline Ukraine & 71 & Ukraine & 76 \\
\hline Somalia & 190 & Somalia & 190 \\
\hline
\end{tabular}

* Prepared according to [11].

Table 2

\section{Ukraine's overall ranking in the Doing Business Ranking and Top Ten Indicators in 2018-2019*}

\begin{tabular}{|l|c|c|c|}
\hline \multicolumn{1}{|c|}{ Key indicators } & $\begin{array}{c}\text { Doing Business } \\
\text { 2018 Rank }\end{array}$ & $\begin{array}{c}\text { Doing Business } \\
\text { 2019 Rank }\end{array}$ & Changes \\
\hline $\begin{array}{l}\text { Rating of Doing } \\
\text { business }\end{array}$ & $\mathbf{7 6}$ & $\mathbf{7 1}$ & +5 \\
\hline by the indicators & 52 & 56 & -4 \\
\hline business registration & 82 & 57 & +25 \\
\hline enforcement of contracts & 29 & 32 & -3 \\
\hline lending & 81 & 72 & +9 \\
\hline investor protection & 149 & 145 & +4 \\
\hline $\begin{array}{l}\text { regulation of insolvency } \\
\text { issues }\end{array}$ & 128 & 135 & +5 \\
\hline connection to the mains & 35 & 30 & +1 \\
\hline $\begin{array}{l}\text { obtaining building } \\
\text { permits }\end{array}$ & 64 & 63 & +41 \\
\hline property registration & 119 & 78 & -11 \\
\hline international trade & 43 & 54 & +5 \\
\hline taxation & & & \\
\hline
\end{tabular}

* Prepared according to [11].

According to the report, other criteria (business registration, tax payment system, access to credit, access to electricity, insolvency resolution were the restraining factors in advancing Ukraine in the ranking - their performance deteriorated.

Thus, despite Ukraine's increasing place in Doing Business, the state of the national business environment still needs significant transformation. Today, there are a number of constraints that impede the development of an effective business environment, as well as reduce the introduction of innovation and investment in the economy, which leads to a decrease in the level of competitiveness of national producers. The main constraints include the imperfection of Ukrainian legislation, political instability, underdeveloped market infrastructure and considerable tax pressure.

Ukraine's strategic priorities for improving the business environment should be reflected in the systematic steps of adaptation of the national economy to changes in globalization processes. This will make it possible to realize the existing innovative and human potential and will become a prerequisite for the gradual enhancement of Ukraine's national competitiveness. The main mechanism for enhancing Ukraine's competitive advantage is the implementation of internal reforms and the transformation of foreign economic policy vectors. 
Conclusion. In the context of rapid globalization changes, the realization of an effective economic policy of the state, by finding an effective and dynamic model of macroeconomic equilibrium, applying effective methods of regulating the economy, substantiating the necessary degree of intervention in economic processes and state policy on the basis of conservation economic interests of the country, should become a necessary condition for the development of a favorable business environment.

\section{REFERENCES}

1. Buryak G. Institutes for the development of property relations in the classification of business environment. Actual problems of international relations. 2012. Vol. 105. Part II. P. 26-28 [in Ukrainian].

2. Coase R. Firm, Market and Law. New Publishing House, 2007. 224 p.

3. Doing Business 2019: Training for Reform. The World Bank. Retrieved from https://www.doingbusiness.org/en/reports/global-reports/doing-business-2019

4. Galchinsky A. Convergent market - methodology of perspective. Economy of Ukraine. 2014. Vol. 1. P. 4-20 [in Ukrainian].

5. Heits V. Overcoming quasi-marketability is the path to an investmentoriented model of economic growth. Economy of Ukraine. 2015. Vol. 6. P. 4-17 [in Ukrainian].

6. Khalatur S. Business environment of Ukraine: theoretical concepts of innovative development. Bulletin of the Kiev National Trade and Economic University. 2019. Vol. 3. P. 16-26.

7. Lipov V. Competitive strategy of development of Ukraine in the conditions of globalization. Economy of Ukraine. 2018. Vol. 4. P. 3-17 [in Ukrainian].

8. Mazaraki A., Lagutin V. Domestic market of Ukraine in an unstable global economy. Bulletin of the Kiev National Trade and Economic University. 2014. Vol. 6. P. 9-23.

9. Nepochatenko O., Prychepa I. Entrepreneurship development in Ukraine: theory, methodology and practice: collective monograph. Uman: Publisher Sochinsky M. 2017. 244 p. [in Ukrainian].

10. Porter M. Competitive Advantage of Nations. Originally published: New York: Free Press. 1990.

11. Rankings \& Ease of Doing Business Score. The World Bank. Retrieved from https://www.doingbusiness.org/en/rankings.

12. Shumpeter J. The theory of economic development. Capitalism, socialism and democracy. M.: Jeksmo. 2007. 864 p.

13. Zhalilo Y. On national features of economic pragmatism. Mirror of the week. 2016. Vol. 49. Retrieved from https://dt.ua/macrolevel/pro-nacionalniosoblivosti-ekonomichnogo-pragmatizmu-_.html [in Ukrainian]. 